\title{
TOURISM INFRASTRUCTURE AS A TOURIST ATTRACTION
}

\author{
Bambang Supriyadi \\ Department of Civil and Environmental Engineering \\ Faculty of Engineering, Universitas Gadjah Mada, Yogyakarta, Indonesia \\ bbsupri@tsipil.ugm.ac.id
}

\begin{abstract}
Infrastructure as one important factor in tourism development has attracted many national tourism planners to increase the number of visitors. It has play an important role in building many sectors such as economy, transportation, social and business. Infrastructures such as bridges have been built as an access for inter-island, inter-provincial, inter-district or inter-regional linkage. This paper presents tourism infrastructure from the bridge's point of view as a tourist attraction. The object of this study is one of the bridges in Yogyakarta region i.e. Srandakan Bridge that connects two municipalities Bantul and Kulonprogo which has great potential to be used as a tourist attraction. The results show that it supports recreational facilities such as water recreation, restaurant and shopping facilities.
\end{abstract}

Keywords - Tourism infrastructure; Tourist attraction; Bridge

\section{INTRODUCTION}

Tourism is one of the potential sources of foreign exchange to the countries and has an important role in building the economy [1]. Indonesia has tourism potential to be developed into a world-class tourism because the country has the beauty of nature, diverse cultural richness and the population whose character and morality support the convenience of tourists visiting. Indonesia has Bali that an already developed, has Raja Ampat that has been in know the world [2]. Currently, Indonesia is developing 10 Priority Destinations that are expected to attract foreign tourists visiting Indonesia, among others destination Toba lake in North Sumatra, Borobudur in Central Java, Mandalika west Nusa Tenggara, Bromo-Tengger-Semeru in East Java, Labuan Bajo in East Nusa Tenggara, Tanjung Kelayang in Bangka Belitung, Kepulauan Seribu in Jakarta, Tanjung Lesung in West Java, Moratai in North Maluku [3,4]. Some of these destinations are the tourism sector that needs to be developed which consists of coastal tourism, mountains, plantations, historical heritage, regional culture, and so on.In the development of a region, infrastructure has a role as a mediator between economic and social systems in the human life order with the natural environment [5,6]. Infrastructure development is a strategy in the provision of infrastructure. The role of infrastructure is not only an influence on regional development, but also on tourism sector. Infrastructure has very important role in encouraging the quality of tourism itself and also on the environment [7]. According to UNWTO in [8] the type of tourism that is in great demand by the public is nature tourism. One type of nature tourism that brings the most tourists, both domestic and foreign tourists is a natural tour.

Tourism in Indonesia has not run optimally, but this aspect is very influential on the increase in income of the people, especially local revenue. Indonesia as a country with

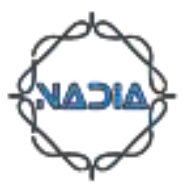


natural resources should be able to use its wealth as an object to bring foreign exchange through nature tourism.

Infrastructure is one of important factors in tourism development. The availability of adequate infrastructure to meet the needs of visitors will certainly increase the number of visitors who visit the tourist area. Provision of good infrastructure needs to be done to improve the competitiveness of these tourist areas. Presently, there are many of the tourism destinations in Indonesia still have not provide supporting adequate infrastructure tourism. Therefore, in the development of tourism, there needs to be plan in providing adequate infrastructure for tourist area. It is supported by Crouch and Ritchie in [9] which suggested that first impressions of tourist visits affect the level of visitor numbers in the region and in this case the availability of adequate infrastructure becomes one important factor to form the experience of tourists who visit a tourist area. One of the causes of the limited the tourism in Indonesia is the presence of the supporting infrastructure in tourism area. Indonesia gets inferior rank, i.e. air transport infrastructure (58), ground transport infrastructure (82), tourism infrastructure (116) and ICT infrastructure (96). These indicators show how poor Indonesia infrastructure which in turn influential to the low competitiveness tourism sector [10].

Poor infrastructure in areas that in fact can be used as a tourist attraction should be developed properly, if infrastructure continues to be developed will be one of the factors that have a positive impact on economic development that can improve the competitiveness of regional economies in the national economy and enhance the competitiveness of national economy to the international economy [11-13].

One of them is the construction of bridge infrastructure. Construction of existing bridges in Indonesia, in addition to being built as access an inter-island, inter-provincial, inter-district or inter-regional linkage. Some examples of bridges in Indonesia are functioning well run is Ampera Bridge. The bridge was have function as a link between Seberang Ulu and the opposite side hilir in separate by the Musi River also as tourist destination, Ampera Bridge is also a symbol of Palembang City [14]. Tayan Bridge connecting the shaft south trans-Borneo, namely East Borneo-South Borneo and West Borneo and Central Borneo which was cut off by Kapuas River in Tayan hilir Distric and several bridges the function of which also be developed as a tourist attraction in the area [15]. One of the bridge that functions as a tourist attraction in the world of Tower Bridge is a bridge that stretches over the River Thames in London, United Kingdom. The bridge was combines two Design Bridge that is lift and hanging. Bridge got this connecting Southwark with north and city of London on the south side. Tower Bridge also be a landmark, and icon the city of London. Hence, the bridge was be tourist destinations, visitors can get in and see the exhibition held in two towers twin bridge, walkway and the engine room bearing. Over there visitors can look around a movie, photos and other display interactive explains history Tower Bridge. Some bridge in Indonesia and function as a tourist attraction of them including (1) Barelang Bridge in Batam, Riau Islands is a symbol of city and icon for Visit Batam Program 2010. It is located 20 kilometers from downtown Batam, Riau Islands Province, Indonesia. Barelang Bridge is six bridges that connect the three major islands and several small islands that are included in the Province of Riau Islands. Barelang own name is an acronym of the three large islands connected by this bridge, namely Batam Island, Rempang Island, and The Galang. (2) Suramadu National Bridge is located in the East Java where this bridge crossing the Madura strait and links between Java with Madura Island. Bridges by $5.438 \mathrm{~m}$ landscape, the bridge was the longest in Indonesia now. (3) Holtekamp Bridge newly constructed and will complete in 2018 in Papua, it connects Hamadi Bridge, the district of South Jayapura with Holtekamp, the district of Muara Tami, and the Jayapura City will be prepared to be a tourist destination in the Jayapura City with a length of 735 meters was above the sea of Humbolt Bay. (4) The Tengku Agung Sultanah Latifah Bridge (also known as the Siak Bridge) is a bridge across the Siak River, Siak Sri Indrapura City, Riau. (5) Rumpiang 
Bridge is the bridge extending above the two, Marabahan City, the district of Barito uala. (6) Kutai Kartanegara Bridge (also known as the Mahakam II Bridge) is a bridge across the Mahakam River that connects Tenggarong Subdistrict with Tenggarong Seberang Subdistrict, Kutai Kartanegara Regency, and East Kalimantan. The length of the bridge as a whole reaches 710 meters. (7) Mahakam Ulu Bridge (abbreviated Mahulu) is a bridge connecting Loa Buah Village, the Kunjang River with Subdistrict Sengkotek, Samarinda across stretching over a stream Mahakam. Initially this bridge will be used as an anticipation of congestion at the PON XVII in Samarinda, east Borneo. (8) Pasupati Bridge or overpass Pasupati is a bridge connecting the northern and eastern Bandung over the Valley Cikapundung. Its length and breadth 2.8 kilometers 30-60 meters, is the second longest bridge in Indonesia. That is a few bridges that would be used as icon tourism in Indonesia.

See the example above the Ampera Bridge in Palembang (as can be seen in Figure 1) and Tower Brigde in London (as can be seen in Figure 2) which has been successfully appointed to be the icon of the city and attractions. One of the bridges in Yogyakarta, namely Srandakan Bridge (as can be seen in Figures 3 and 4) that connects Bantul and Kulonprogo districts has great potential to be used as a tourist attraction.

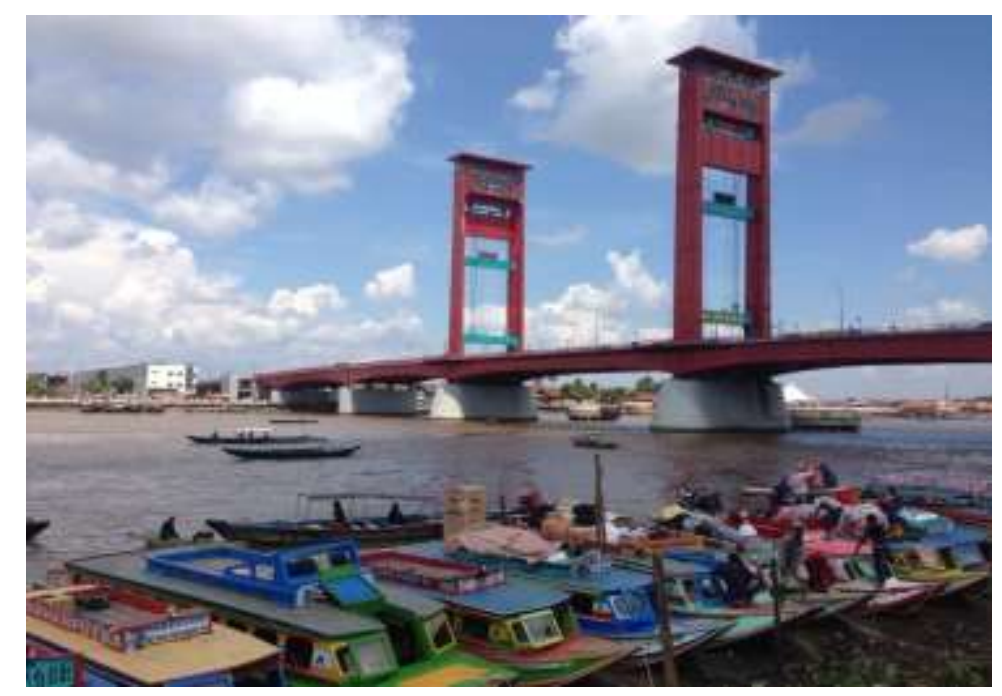

Fig. 1 Ampera Bridge in Palembang

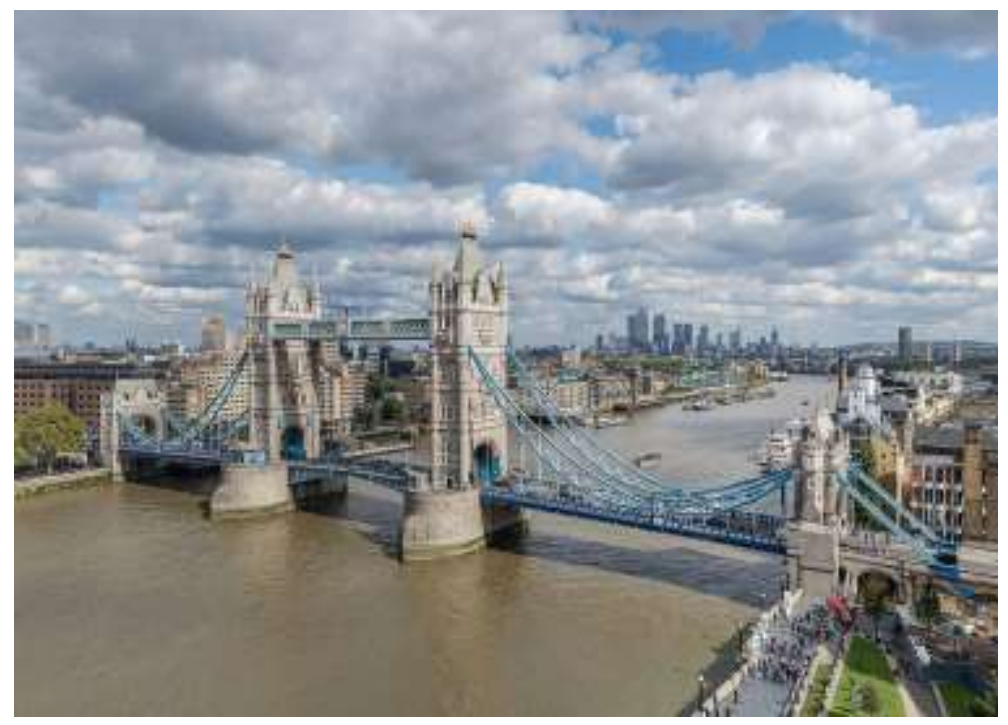

Fig. 2 Tower Bridge in London 


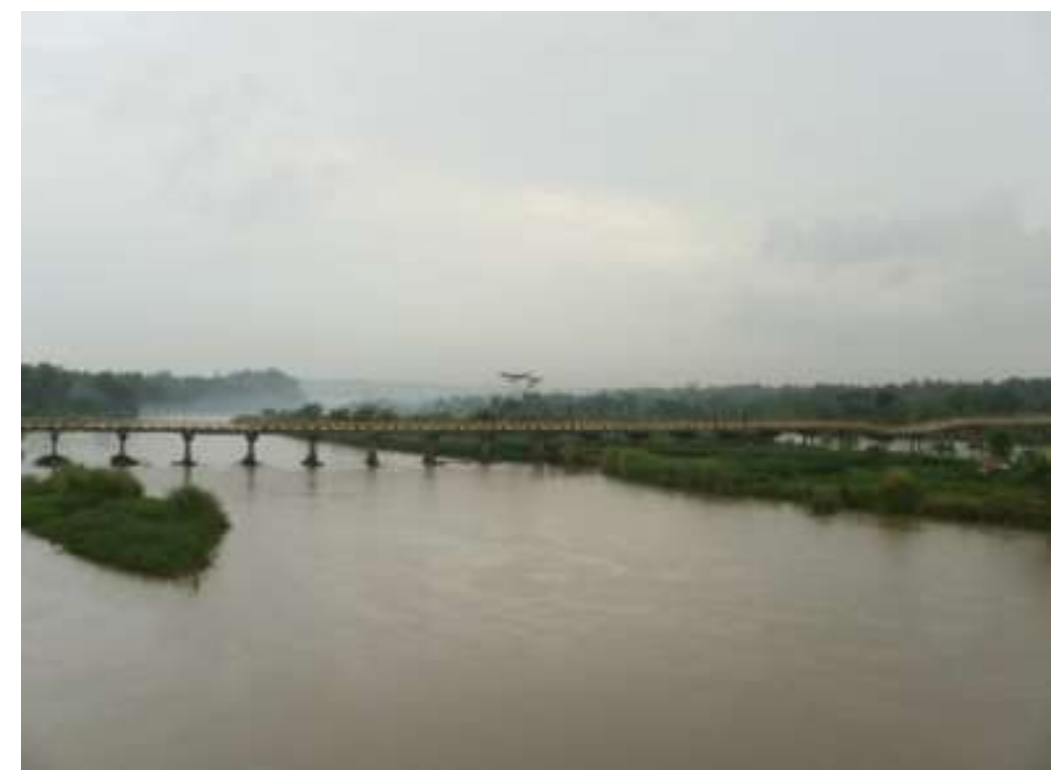

Fig. 3 Srandakan Bridge in Yogyakarta

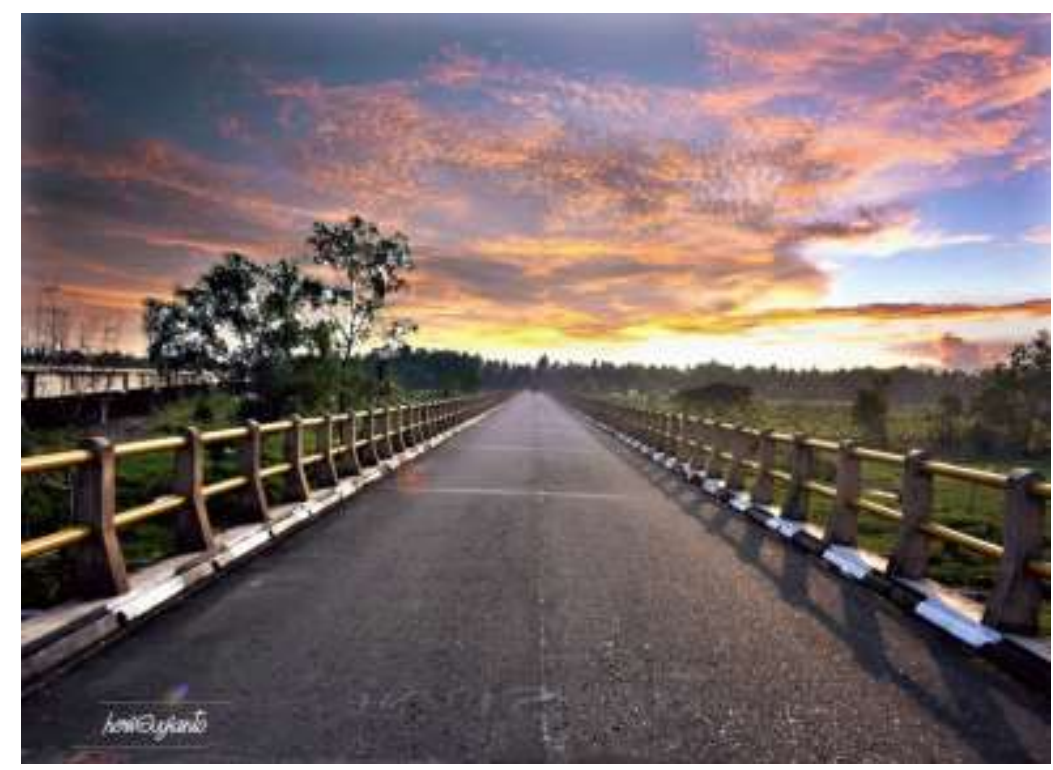

Fig. 4 Srandakan Bridge in sunset view

During this Srandakan Bridge only functioned as access between districts, however its existence can be used as a tourist attraction when local government see more focused will the potential to support tourism in Yogyakarta by managing the bridge better. This due to the construction of international airport being built in the district of Kulon progo. Therefore, later the Srandakan Bridge will be an alternative the way across south. Therefore, the authors want to explore more about the bridges in Indonesia and Srandakan Bridge in particular as a tourism infrastructure that can be used as a tourist attraction.

This paper presents tourism infrastructure from the bridge's point of view as a tourist attraction. The object of this study is one of the bridges in Yogyakarta region i.e. Srandakan Bridge that connects two municipalities Bantul and Kulonprogo which has great potential to be used as a tourist attraction. The results show that it supports recreational facilities such as water recreation, restaurant and shopping facilities. 


\section{RUDIMENTARY}

\subsection{TOURISM INFRASTRUCTURE}

Definition of infrastructure according to American Public Works Association [6], is physical facilities developed or needed by the public agents for the functions the crown in water supply, electric power, the waste disposal, transportation and services similar to facilitate social and economic goals. So infrastructure is physical system needed to meet the needs of basic human within the scope of social and economic. In this case, the natural environment is an infrastructure system, and economic system supported by infrastructure system, a social system as an object and targets of supported by economic system. The analogy as the Figure in the following:

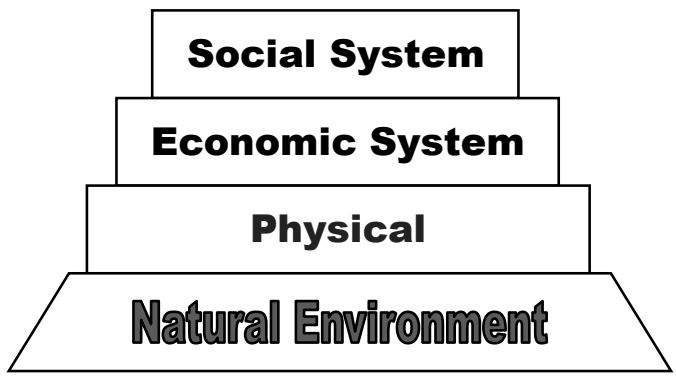

The natural environment is for supporting infrastructure.

Economic system supported by infrastructure system

Supported by economic system

Fig. 5 Infrastructure system analogy

Based on Figure 5 above, it can be seen that the natural environment is supporting the basis of all existing system. The role of infrastructure as a mediator between the economic system and social in its life to remain supported by the natural environment infrastructure system can be divided into:
a. Group of the aquatic
b. Group of the distribution and energy production
c. Group of the communication
d. Group of the transportation
e. Group of the buildings
f. Group of the transportation services
g. Group of the waste management

Based on American Public Works Association [6] infrastructure is defined as physical facilities developed or needed by agents of the public for the functions the crown in water supply, electric power, the waste disposal, transportation and services similar to facilitate the purpose of economic and social. While in other definition infrastructure is a physical system that provides transportation, irrigation, drainage, the buildings public buildings and facilities another required to meet the needs of basic human in scope social and economic [5]. In other words infrastructure is physical assets designed in the system so providing important public services. Infrastructure could be divided into 13 categories based on the definition of infrastructure by Grigg in [5] among others:

a. The water supply system : reservoir, the water storage, transmission and distribution of water processing facilities 
b. The processing waste disposal system : intermediary, processing, basic disposal repeated

c. The processing (treatment) facility for solid waste

d. The flood control, drainage, and irrigation

e. The inland waterways facility and navigation

f. The transportation facility : railways, airport

g. The public transit systems

h. The electricity system

i. The natural gas facilities

j. The public buildings : school, hospital

k. The public housing facilities

1. City parks as an absorption, a playground including stadium

m. Communication

Development relations with the infrastructure planning is a system to change toward for better system as a support social and economic system as well as a connecting with system of the environment in the system space eventually build economic development of an areas.

\subsection{Tourism Object}

Tourism Object is one of important components in tourism industry and one of the reasons visitors traveled (something to see). In overseas a tourism site is called tourist attraction, while in Indonesia more recognized with tourism object. To the meaning tourist attractions, we can see from sources among other:

a. Indonesian Government Rule No.24/1979

Tourism is embodiment of human creation, the life, cultural and historical nations and the state of nature have attraction to attend

b. Decree of the Ministry of Tourism, Post and Telecommunications (MENPARPOSTEL) No.KM.98/PW:102/MPPT-87

A tourist attraction is a place or a state of nature has the resources tourism that is built in and developed so that has its pull and commonly found as a facility to visited by tourists. According to Yoeti in [16], an area to be good tourist destinations should develop three things that the area interesting to attend, namely:

a. The existence of something that can be seen (something to see), and what it interesting to be watched, in this case tourism different from other places have the unique). Besides should also be concerned about tourist attraction which can be used for entertainment if the visit later

b. The existence of something that can be bought (something to buy), are something interesting that typical for be acquired in this used as souvenir to be carried returned to the each place so that in the area have to there are facilities to be shopping that provides souvenirs and craft the other hand and must also supported by other facilities as money changer and bank.

c. The existence of something that can be done (something to do), namely an activity that can be conducted in a place is who can make people feel stay on the spot. 
Information from above, we can conclude that an attraction good and interesting to attend should have natural beauty and must also be to its uniqueness and allure to and visited also supported by when enjoyed facilities.

\section{METHODOLOGY}

This study aims to find the potential development of tourism supporting infrastructure, especially the bridge to serve as a tourist attraction. The author uses descriptive method, literature study and location observation study. According to Syah in [17] that descriptive research is a research method used to find the knowledge as far as possible to the object of research at a certain time. Meanwhile, according to Setyosari in [18] explains that descriptive research is research that aims to explain or describe a state, event, object whether people or anything related to variables that can be explained either by numbers or words. This work stroves that photographing events and developments that became the center of his attention, then describe or describe just as there are. Therefore, the utilization of research findings this is not necessarily relevant when they are used, since it does not always insisting on the existence of the hypothesis.

Literature studies are done to deepen the concepts used in this research. Observation location study was data collection method through review carefully and directly in the field or location research with the goal of gaining a description of the development and the state of infrastructure, that is tourist attractions.

\section{RESULTS AND DISCUSSION}

Based on the results of study of literatures, comprehensive Tourism is defined as an industry engaged in the field of service that compromises various measurable and immeasurable elements. The measurable elements include transportation systems and hospitality services (accommodation, food and beverage, tours, and other services such as financial services, security, and convenience). Mc Intosh [19] argues that the infrastructure and its supporting facilities are included in the tourism supporting component, while according to Musenaf [20], the infrastructure included in the components of a tourist area covering the road infrastructure, electricity, hygienic water, telecommunications and tourism facilities which include accommodation facilities and restaurants. Further, Yoeti in [16] stated that one of the objects of offerings in tourism marketing is the supporting infrastructure of tourism, among others:

a. Recreate and Sportive Plan

b. Residential Tourist Plan, consisting of lodging / hotels and places for meal / restaurants

c. Means of complementary or supporting tourism to make tourists can stay longer in the tourism sites

d. Means of sale, in the form of shops that sell souvenir items or other special objects for tourists

e. Utilities, which are related to the availability of clean water, electricity, drainage and sanitation networks (availability of toilet facilities)

f. Social infrastructure, such as education and health facilities

g. Transportation, namely the availability of transportation facilities (modes of vehicles used to the sites) and accessibility (ease of access to the tourist area)

Based on the above theoretical sources, the tourism infrastructure variables selected in this study include: 


\section{a. Recreational facilities of water recreation \\ b. Restaurants / places to eat \\ c. Shopping departments (shops, souvenirs)}

The 'Tower Bridge' bridge was built in 1886 and has been managed very well with various facilities supporting tourism therefore it is now the most famous for tourists in London, England. With the entrance ticket, visitors can walk in the Tower Bridge and enjoy the most amazing view from the top of the tower. One of the most unique things about Tower Bridge is this bridge is cut in half in the middle so that the two sides of the bridge can be lifted. The two sides of this bridge can be lifted up to $86^{\circ}$, allowing underwater water traffic, especially ships with tall poles to pass through. This is the initial idea that underlies the design of this uplifting bridge, as a solution to the problem of ordinary bridges that high ships cannot pass through. The Tower Bridge has a very interesting historical value to know. Indeed, there is a museum located inside the old engine room where the visitors can see the original steam engine and hydraulic machine that was first used to lift the middle part of the Tower Bridge.

Back then, the Tower Bridge can be lifted up to almost 50 times per day $(18,250$ times / year), but currently is only about 1000 times a year. The lifting mechanism of the bridge is carried out with a hydraulic system, whereas the lifting arrangements are made through signal communication between the bridge operator and the large ship that will pass through. The computer system was installed in 2000 to remotely control the elevation and demotion of the center of the bridge. Currently the Tower Bridge is still a busy and vital bridge to cross the Thames. This bridge is crossed daily by more than 40,000 people, consisting of motorists, cyclist, and pedestrians. To maintain its structural strength, the bridge management imposed a maximum speed limit of $32 \mathrm{~km} / \mathrm{h}$ and a load of 18 tons for vehicles that cross over the Tower Bridge. The camera system is used to measure the speed of the passing vehicles, by integrating the vehicle license plate recognition system to send a fine bill to the driver who has advanced his vehicle over the speed limit. The sensor system is also applied to measure the total weight, height of the bottom frame, and the number of wheels of each passing vehicle.

Meanwhile in Indonesia, there is Ampera Bridge which its function is almost the same as the Tower Bridge in London. The Ampera Bridge is a bridge of pride of Palembang society in South Sumatra and becomes the Trade Mark for the city of Palembang. The Ampera Bridge is indeed a Bung Karno's prize for Palembang people which funds are taken from the spoils of battle against the Japanese colonials (of funds was also to build the Monas in Jakarta). Formerly this bridge was named 'Bung Karno Bridge' but he did not agree as so to make no cult of the individual. Then, the name Ampera is more suitable in accordance with its function as the 'Amanat Penderitaan Rakyat' (the Mandate of People Agony', which had become the slogan of Indonesia in 1960s.

Initially, the center of the body of this bridge can be lifted up so that the mast of the ship passing underneath is not caught by the body of the bridge. The center of the bridge can be lifted with mechanical equipment with two pendulum weights of about 500 tons each in its two towers. The lifting speed is about 10 meters per minute with the total time it takes to fully lift the bridge is 30 minutes. By the time the center of the bridge is lifted, the ship with a width of 60 meters and with a maximum height of 44.50 meters can pass through the Musi River. When the center of the bridge is not lifted, the maximum ship height that can pass under the Ampera Bridge is only nine meters from the water surface. However, since 1970, the Ampera Bridge has ceased its elevation and demotion activities. The reason is that the time used to lift this bridge, which is about 30 minutes, is considered to disrupt traffic flow between Seberang Ulu and Seberang Ilir, two areas of Palembang City separated by the Musi River. Another reason is because in fact the large ships are no longer able to sail on the Musi River. The increase of silting becomes the 
cause for the large ship not be able to cross the Musi River. Until now, Musi River is continuing to experience the siltation.

Broadly speaking, the bridges in Indonesia have functioned well, where it is just that the infrastructure is located in areas which are not optimally functioned as a supporter of tourism. One example of the bridge in the area that can still be optimized function as a support for tourism in the Special Region of Yogyakarta, especially in Bantul and Kulon Progo is the Srandakan Bridge. Here's the explanation. The general description of the tourism infrastructure is as follows:

\subsection{GENERAL ASSESSMENT OF SRANDAKAN BRIDGE INFRASTRUCTURE, BANTUL}

a. Recreational facilities of water recreation

The Srandakan Bridge crossing the Progo River is the only connector between Bantul district and KulonProgo in the south. The Srandakan Bridge across the Progo River is one of the longest bridges in Java Island with the length of about 531 meters. So far, the bridges have only functioned as connecting access between Bantul and KulonProgo districts and there is no place that can be used as water recreation site such as duck boat, speedboat, jet ski, or open rafting line. Visitors will also be able to enjoy the sunset in the afternoon. To make the area becomes more interesting, the architecture in the bridge can be added with good lighting facilities.

b. Restaurant/ food places

In the surrounding area will be opened several places to eat that combine typical food from Bantul area e.g. gudeg manggar and Kulon Progo area bengok santen.

\section{c. Shopping facilities}

Nearby the Srandakan Bridge, there is no facilities for shopping so it is possible to build a souvenir center that became the characteristic or the result of handicrafts surrounding communities. In addition to the shopping center, it is also possible to build a mini museum that explains the history of the bridge as a historical relic of the Dutch colonialization.

\subsection{STUDY ON SUPPORTING INFRASTRUCTURE DEVELOPMENT AT SRANDAKAN BRIDGE, BANTUL AS A TOURISM OBJECT}

The availability of and support to the tourism infrastructure facilities is essential because it is the first aspect that is very influential to the progress of tourism in Bantul and Kulon Progo districts. The existence of excellent tourism infrastructure and facilities will create a favorable tourism conditions as well as readiness to compete with the attractions in other regions.

\subsection{FORMULATION OF THE STRATEGY}

The formulation of development strategy of the supporting infrastructure at Srandakan Bridge to serve as tourism object can be described as follows:

a. Increasing Quantity and Provision of Tourism Support

Improving the quality and quantity of basic tourism infrastructure and facilities is done by maintaining and improving the capacity of infrastructure facilities; as well as building the infrastructure and facilities in accordance with the priorities, objectives, and aims of tourism area development on the Srandakan Bridge, Bantul. For example, the construction or maintenance of road infrastructure to the location, the establishment of tourism facilities/support for example: lodging facilities, culinary places, toilets, gift 
shops, parking lots, places of worship, etc. This is done in order to improve the quality of tourism to meet the needs of the visitors.

\section{b. Improving Quality and Service of Tourism Supporting Infrastructure}

The strategy to improve the quality and service is by expanding the network of basic infrastructure services such as the clean water and electricity network as well as repairing the damaged public facilities. Further, support from government agencies such as the Tourism Office by providing support for tourism education to local communities or local governments is also helpful to support the funding of small community enterprises that support the tourism.

c. Increasing Participation/Community Involvement in the Maintenance of Tourism Supporting Infrastructure

Involving the community in developing tourism supporting infrastructure is important so that the community becomes a part of the effort. The community is a resource that is able to keep and maintain the existing sites, including the supporting infrastructure for tourism.

d. The Establishment of Special Institutions That Can Strengthen the Cooperation with Private Parties in Infrastructure Development

The stakeholders related (the government and community) also need to make efforts in partnership by involving the private sector / investors who have the potential to invest. In addition, it also develops partnerships with funding agencies (banks or non-banks) to create new investments in order to develop the infrastructure of Srandakan Bridge, Bantul as a tourist attraction. In this case, the government can provide feedback to investors by providing ease of licensing and investment incentives in the area of Srandakan Bridge. The local government is obliged to implement coordination, planning, implementation, and monitoring of the development of infrastructure and supporting tourism facilities, as well as to improve the integration of regional development planning that is capable of being the local economy's driving force in a sustainable manner. Thus, inter-sectoral integrity can be achieved; all institutions run in an integrated way with giving importance to the public interest, be serious, and sustainable. The roles of the government as the highest authority holder whichis more assertive over the applicable regulations are to conduct field studies and to conduct the periodic evaluations.

\section{CONCLUSION}

One type of infrastructure that should often be built in the development of tourist areas is a bridge. This paper has presented tourism infrastructure from the bridge's point of view as a tourist attraction. Bridges that have functions primarily linking roads separated by rivers / valleys or other obstructions, are built to facilitate / accelerate access roads to tourist areas. It is observed that most of the bridges built in Indonesia are still more concerned with road connecting functions, although for access to tourist areas. Based on the results on the study of the Tower Bridge in London, it is concluded that the environment surrounding the Tenggarong Bridge, Suromadu Bridge, and etc. The development of the Srandakan Bridge connecting Bantul and Kulon Progo areas where many tourist areas are proposed, Srandakan Bridge is also developed as a tourist attraction, water tours, restaurants and souvenir shops.

\section{REFERENCES}

[1] Tugcu, C.T. (2014). Tourism and economic growth nexus revisited: A panel causality analysis for the case of the Mediterranean Region. Tourism Management, 42, 207-212. 
[2] Ernawati, N. M., Sanders, D., \& Dowling, R. (2017). Host-Guest Orientations of Community-based Tourism Products: A Case Study in Bali, Indonesia. International Journal of Tourism Research, 19(3), 367-382.

[3] Law, A., DeLacy, T., \& McGrath, G. M. (2017). A green economy indicator framework for tourism destinations. Journal of Sustainable Tourism, 25(10), 1434-1455.

[4] Subandi, M. R., \& Putra, F. K. K. (2017). Website evaluation for the local tourism offices of Indonesia's top 10 priority destinations.

[5] Grigg, N. 1988. Infrastructure Engineering and Management, John Wiley \& Sons.

[6] Kodoatie, Robert. 2005. Pengantar Manajemen Infrastruktur. Yogyakarta: Pustaka Pelajar

[7] Roberts, L., Hall, D., \& Morag, M. (2017). New directions in rural tourism. Routledge.

[8] UNWTO. 2014. UNWTO Tourism Highlights http://unwto.org accessed date on August $8^{\text {th }} 2017$

[9] Crouch, G.I. amd Ritchie, J.R.B. (1999): 'Tourism, competitiveness and societal prosperity". Journal of Business Research, 44 (3), pp. 137-152.

[10] http://www.selasar.com/2012

[11] Butler, R. W. (1991). Tourism, environment, and sustainable development. Environmental conservation, 18(3), 201-209.

[12] Kotler, P., \& Gertner, D. (2002). Country as brand, product, and beyond: A place marketing and brand management perspective. Journal of brand management, 9(4), 249-261.

[13] Getz, D. (1992). Tourism planning and destination life cycle. Annals of tourism research, 19(4), 752770.

[14] Kusumaningrum, D. (2009). Persepsi wisatawan nusantara terhadap daya tarik wisata di Kota Palembang (Doctoral dissertation, Universitas Gadjah Mada).

[15] Liu, P., \& Liu, Y. (2017). Design and Stability Analysis of Temporary Tie Rod of Tayan Bridge Segment Integral Lifting. Technology of Highway and Transport, 2, 009.

[16] Yoeti, Oka. 1985. Pengantar Ilmu Pariwisata. Penerbit Angkasa. Bandung

[17] Syah, H. 2010. Penelitian Deskriptif. Jakarta: Rajawali.

[18] Setyosari, 2010, Metode Penelitian dan Pengembangan, Kencana, Jakarta

[19] Mc. Intosh, Robert W, dan Charles R. Goeldner. 1995. Tourism Principles, Practices, Philosophies. USA: Great Publishing Inc

[20] Musenaf, Drs. 1995. Manajemen Usaha Pariwisata Indonesia, Jakarta: Penerbit PT. Toko Gunung Agung. 
International Journal of Advanced Science and Technology Vol.130 (2019) 